Pour évaluer un schéma de sélection il est nécessaire d'en établir le coût et d'estimer les gains qui peuvent en résulter. Les facteurs qui influencent ces coûts et ces gains sont nombreux: méthode de sélection, intensité de sélection annuelle, répartition des coûts dans la sélection des deux sexes, vitesse de diffusion des gènes du noyau de sélection aux producteurs, taux d'actualisation des profits, durée des opérations, etc. En outre, selon que l'on considère la rentabilité (gain/cont) ou le profit (gain-cout) les solutions les meilleures sont différentes.

Siler, Podebradsky et KVapil évaluent économiquement l'ensemble du système sélectioncroisement appliqué en Tchécoslovaquie, alors que LindHE et Holmouist-ARBRANDT placent leur étude dans les conditions de la plupart des pays d'Europe occidentale, avec utilisation par les sélectionneurs de stations de sélection d'État.

L'évaluation économique précise d'un schéma de sélection est plus difficile si l'on se place, comme le fait BICHARD, dans le cadre d'une entreprise privée de sélection face à un marché concurrentiel de reproducteurs. Des facteurs extra-génétiques et extra-économiques deviennent alors importants pour conquérir et garder ce marché, et l'efficacité économique doit être jugée d'un point de vue dynamique.

\title{
ECONOMIC EFFICIENCY OF PIG BREEDING SCHEMES. A BREEDING COMPANY VIEW
}

M. Bichard. - Pig Improvement Company, Fyfield Wick Abingdon, Oxon. OXI3 ${ }_{5} \mathrm{NA}$, England.

Economic efficiency in a breeding scheme is something dynamic. It is not possible to study the situation, decide on the perfect solution and then implement it. Instead it is essential to construct something which is initially sound, based upon as wide a view of the industry's requirement as it is possible to gain; this must then be allowed to respond continuously to new knowledge and changing conditions. This review has examined some aspects of pig breeding schemes which affect their economic efficiency. These include the type of crossbreeding system, the selection applied within the lines, the importance of starting up relatively quickly, of maintaining efficient production within the breeding herds and of structuring the scheme so that improvements are passed down quickly to the commercial slaughter pigs.

\section{ECONOMIC EFFICIENCY OF PIG BREEDING SCHEMES Aspects on a national two breeds program}

B. Lindhé and L. Holmguist-Arbrandt. - Association for Swedish Livestock Breeding and Production (SHS), S-63r 84 Eskilstuna, Sweden.

The main result of the present investigation is to illustrate how a model for pig selection can look like, and the effect on $\Delta \mathrm{G}$ and profit if certain important factors are varied within the given model. The most time consuming part of the work has been to find a model simple enough to make it possible to understand what is going on when certain variables are changed but at the same time complicated enough to cover necessary requirements. So far the model is by no means good enough to allow far reaching conclusions to be drawn. The only thing so far achieved is that the consequences of different testing programs have been illustrated in genetic as well as economic terms.

As the arsenal of tools available to decision makers in pig breeding is getting more and more varied as well in terms of costs as in terms of effects, the need for an evaluation of the optimum combination of these tools is urgent. Breeding operation research is a new branch in the science of animal breeding. The models, worked out for dairy cattle already have affected the applied breeding schemes to a very large extent. The corresponding development in the field of pig breeding lies still in the future.

\section{ECONOMIC ASPECTS OG THE HYBRIDISATION PROGRAMME IN PIG BREEDING}

R. Siler, Z. Podìbradsky, O. Kvapil. - Research Institute for Animal Production Prague ro, Uhrineves Research Institute for Pig Breeding, Kostelec upon Orlice, Czechoslovakia.

At the production of slaughter pigs in large scale conditions the knowledge of basic economic features of all links of the whole production chain is of great importance. The distribution of the total profit in relation to the amount of work put in individual production sections is important. 
For the production of slaughter pigs by means of the hybridisation programme the economic evaluation of the own breeding work is very valuable. The detailed economic examinations have shown very clearly a tremendous space for the improvement process and an enormous return of investments put in this sphere. This follows from the number of final hybrids and from have shown very clearly a tremendous space for the improvement process and an enormous the amount of production of slaughter pigs per sow in elite herd. The profit function constructed for Czechoslovak conditions is presented and its use is shown. The solid knowledge of economic relations and functions in the whole process of production of slaughter pigs is thus becoming an unavoidable assumption for the management of the whole pig breeding.

\section{Prüfungsmethoden, Populationsstruktur und ökonomische Parameter in ihrem Einfluss auf die Zuchtplanung beim Schwein}

\section{E. NiEBEL. - Institut für Tierhaltung und Tierzüchtung der Universität Holenhein, BRD.}

Auf der Basis eines umfassenden EDV-Programms für die Reinzucht beim Schwein wird versucht, den wirtschaftlichen Erfolg der Planungsarbeit mit Hilfe der Kriterien des Zucht fortschritts je Jahr, des Kapitalwerts, der Pay-Off-Periode, der internen Verzinsung und der marginalen internen Verzinsung aufzuzeigen. Zur Quantifizierung des Zuchtziels wurde ein Gesamtzuchtwert aufgestellt, in dem die Leistungsmerkmale tägliche Zunahmen, Anteil wertvoller 'Teilstücke und Anzahl aufgezogener Ferkel berücksichtigt wurden. Die dafür notwendigen Wirtschaftlichkeitskoeffizienten wurden der Arbeit von BockENHOFF und al. (1976) entnommen. In den Planungsrechnungen wurde außerdem das genetische Niveau des Merkmals der Fleischhelligkeit konstant gehalten. Die Modellrechnungen erstreckten sich schwerpunktmäßig auf die Ermittlung der Effektivität unterschiedlicher Prüfungsmethoden von Ebern und Sauen sowie auf die Faktoren der Populationsstruktur.

Als vorläufige Ergebnisse der Modellrechnungen sind herauszustellen:

- Zuchtfortschritt, Kapitalwert, interne Verzinsung und Pay-Off-Periode führen bei der Beurteilung der Zweckmäßigkeit von Planungsalternativen beim Schwein zu ähnlicher Rangfolge

- die Voll- und Halbgeschwisterprüfung der Eber in Station in Kombination mit einer Eigenleistungsprüfung im Feld ergibt auch bei konstantem genetischen Niveau der Fleischhelligkeit einen befriedigenden Selektionserfolg, dagegen fällt die Eigenleistungsprüfung unter Restriktion in ihrer züchterischen Bedeutung stark ab

- durch die Einbeziehung der aus der Stationsprüfung verfügbaren Informationsquellen in die Zuchtwertschätzung der Sauen kann der Züchtungserfolg wesentlich gesteigert werden

- in der Zuchtplanung für die Reinzucht beim Schwein kommt den Faktoren der Populationsstruktur eine überragende Bedeutung zu. Auf die züchterische Relevanz der hier untersuchten Faktoren Prüfungskapazität in Station, Eber-Sauen-Verhältnis, Anzahl Selektionspfade bei der Genübertragung, Größe der Prüfgruppen und Zahl der Prüfgruppen je Eber wird hingewiesen.

\section{Zur EfFizienz der Zuchtwertschatzung von Jungsauen im Feld}

\section{W. Peschke und G. Averdunk. - Bayerische Landesanstalt für Tierzucht, 8oit Grub/BRD.}

In der bayerischen Herdbuchzucht (DL) wurden insgesamt 9216 Jungsauen im Feld geprüft und für die Merkmale der Eigenleistung (Zunahme, Speckdicke und Schinken) ein innerbetrieblicher Zuchtwert berechnet. Von 509 dieser Jungsauen wurden Nachkommen auf der Station geprüft. Die Parameter der Feldprüfung stimmen mit denen der Literatur weitgehend überein. Bei der Beurteilung der Selektionsdifferenzen ergeben sich Unterschiede zwischen Vollgeschwistern und Nachkommen. Als mögliche Ursache können in Frage kommen : die disassortative Anpaarung der selektierten Jungsauen, die unbefriedigende Erfassung der Zunahme bei hohen Lebendgewicht, sowie genetische Unterschiede zwischen Herden. Die Berücksichtigung der Geschisterinformation oder des genetischen Niveaus auf Grund der Stations-ergebnisse könnten diesen Index verbessern, doch sind hierfür weitere Untersuchungen notwendig. 